U. S. DEPARTMENT OF THE INTERIOR

U. S. GEOLOGICAL SURVEY

GEOLOGIC IMPLICATIONS OF DATA FROM THE AMERICAN QUASAR 27-22

HAGENBARTH DRILLHOLE, BEAVERHEAD COUNTY, MONTANA

by

William J. Perry, Jr.'

OPEN-FILE REPORT 98-30

This report is preliminary and has not been reviewed for conformity with U.S. Geological Survey editorial standards.

'MS 939, Federal Center

Box 25046

Denver, CO 80225-0046 


\title{
GEOLOGIC IMPLICATIONS OF DATA FROM THE AMERICAN QUASAR 27-22 HAGENBARTH DRILLHOLE, BEAVERHEAD COUNTY, MONTANA
}

by

\author{
William J. Perry, Jr.
}

\section{INTRODUCTION}

The American Quasar 27-22 Hagenbarth was drilled to a total depth of $12,048 \mathrm{ft}$ $(3,672 \mathrm{~m})$ as a rank-wildcat exploratory test for oil and gas in the south-central part of the McCartney Mountain salient, a second-order salient within the northern part of the southwestern Montana recess of the Cordilleran thrust belt (fig. 1, table 1). The Hagenbarth drillhole is significant for a number of reasons: (1) it reached crystalline basement; (2) it appears to have encountered a thin sequence of Proterozoic Belt sandstone just above crystalline basement and thus appears to help define the southern margin of the Belt embayment in this area; (3) thermal maturation data, analyzed from cuttings of this drillhole, help define the oil and gas potential of the region, and (4) a close comparison of the computed thicknesses of the different units encountered in the drillhole with nearby surface sections help better define paleotectonic features in the area surrounding the McCartney Mountain salient.

The geology of the McCartney Mountain salient was principally studied by Brumbaugh (1973), Brumbaugh and Hendrix (1981), Brandon (1984) and Schmidt and others (1988). Lopez and Schmidt (1985, fig. 7) show an east-west structural section, near the drillhole, based in part on a seismic reflection line. They interpret an east-vergent thrust complex, containing abundant imbricated thrusts of relatively small individual (generally less than $1 \mathrm{~km}$ ) displacement (Lopez and Schmidt, 1985, fig. 7 ; Schmidt and others, 1988, fig. 23). I measured the length of the Triassic/Permian (Mz/P) contact on their cross section to be 40.8 $\mathrm{km}$ over a horizontal distance of $22.3 \mathrm{~km}$. The indicated shortening is thus $18.5 \mathrm{~km}$ over an estimated original distance of $40.8 \mathrm{~km}$. The shortening ratio $\Delta \mathrm{l} / \mathrm{I}_{\circ}$, where $\Delta \mathrm{l}$ is the shortening in $\mathrm{km}$ and $\mathrm{I}$. is the calculated original distance in $\mathrm{km}$, is 0.4534 which rounds to $45 \%$ shortening. Thus, in spite of the modest amount of shortening represented by any one thrust, the cumulative shortening in the McCartney Mountain salient is quite significant.

A preliminary K/Ar date of $70 \pm 1.5$ my from a stock that cross-cuts the thrusts, reported by Brumbaugh (1973), has been widely used to date this part of the thrust belt (Ruppel and Lopez, 1984; Schmidt and others, 1988). It should be emphasized that this may be younger than the bulk of the thrusting in the area, but contractional deformation farther east, along the eastern edge of the Helena salient (fig. 1) continued into the late Paleocene and earliest Eocene (Harlan and others, 1988).

\section{ACKNOWLEDGMENTS}

I wish to thank officials with the former American Quasar Petroleum Company for providing logs and cuttings from the 27-22 Hagenbarth drillhole; Juanita McKenzie, formerly with USGS, for laboratory preparation and description of cuttings obtained from American Quasar; Jerry L. Clayton, USGS, for providing RockEval results, Alonzo H. Love, USGS, for kerogen color and TAI; Mark J. Pawlewicz, USGS, for vitrinite reflectance measurements, and Charles A. Sandberg, USGS, for conodont age and CAI results as well as helpful suggestions concerning the present report. I also wish to thank J. Michael O'Neill for many helpful comments. 


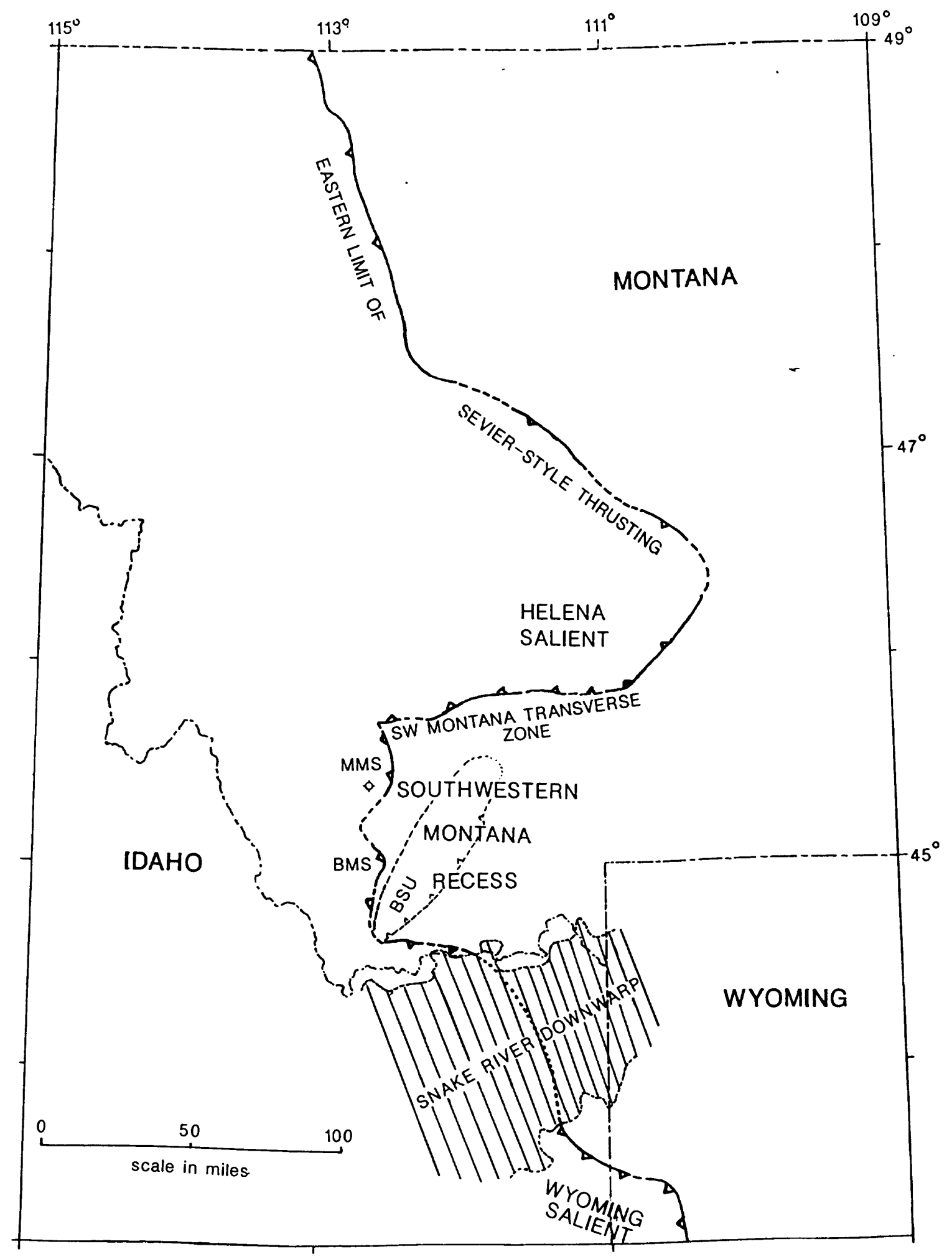

Figure 1. Index map showing front of Cordilleran thrust belt in Montana as well as tectonic features described by Perry and others (1989). Location of 27-22 Hagenbarth drillhole shown by dry hole symbol just below MMS. BMS - Blacktail Mountains salient; BSU Blacktail Snowcrest uplift; MMS - McCartney Mountain salient. 
Formation and member tops and bases, in the American Quasar 27-22 Hagenbarth drill-holes (table 1) are based primarily on my interpretation of the borehole compensated sonic log, both sonic and gamma ray curves, in conjunction with the formation density log and mudlog record of lithology of returned drill cuttings. I calculated formation thicknesses from drilled intervals (log tops minus log bases) based on the publicly released dipmeter arrow plots (dip azimuth vs. dip magnitude) for the drill-hole interval 1,002 to $7,918 \mathrm{ft}$. I used an eyeball average for consistent (more than three) nearby readings, eliminating data scatter that is likely due to fractures, cross-stratification, or miscorrelation of resistivity curves:

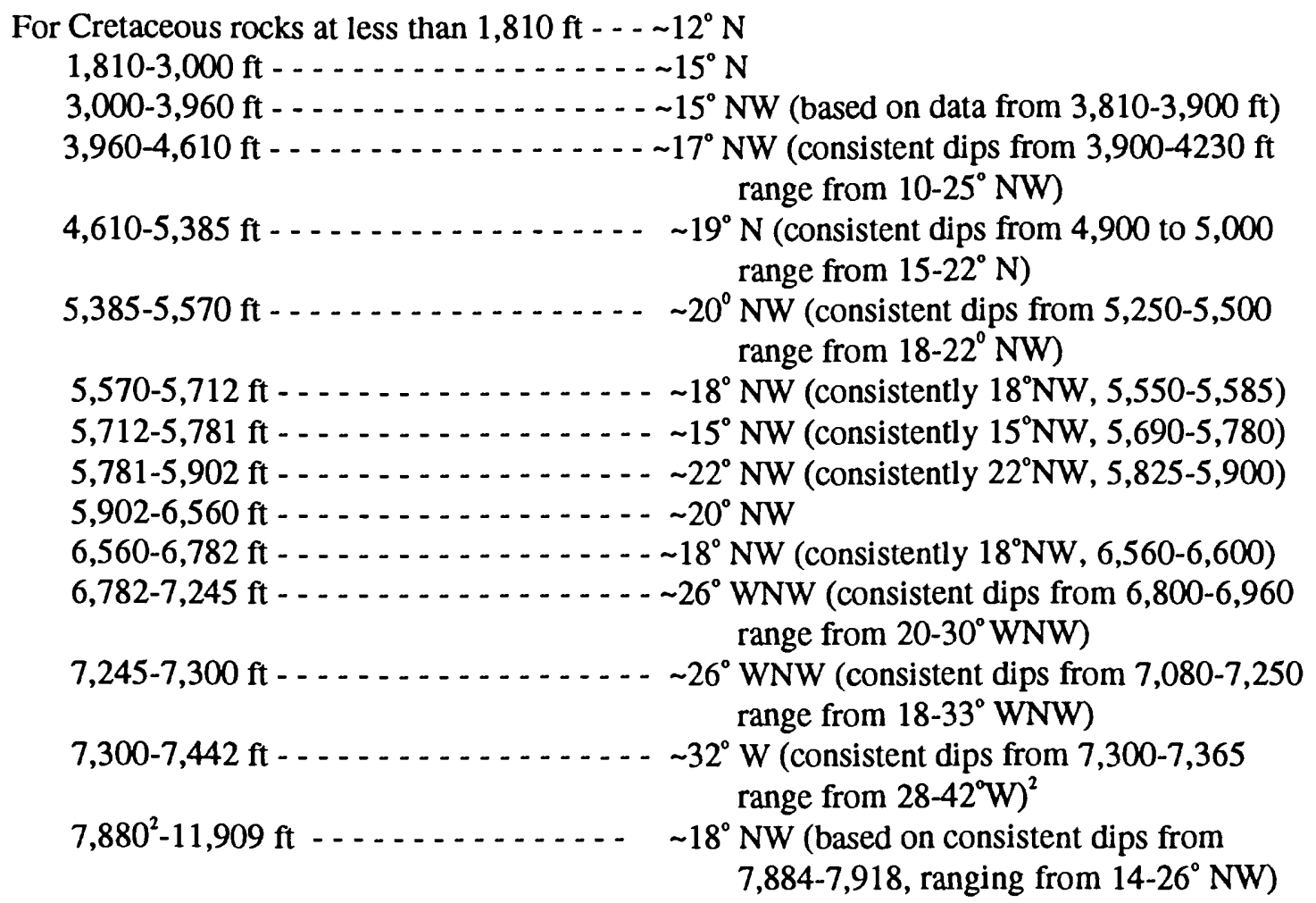

1. The dipmeter HDT logging tool uses " 4 pads, $90^{\circ}$ apart, mounted on hydraulically actuated arms" which provide focused "micro-resistivity curves" of the adjacent borehole margin, giving deeper and narrower penetration than the older three pad CDM tool (Schlumberger, 1970, Fundamentals of dipmeter interpretation, p. 1). The four resistivity curves are normally matched by computer analysis; the released arrow plot specifies that it was obtained from a "cluster program", computed October 15, 1980.

2. Dip magnitudes decrease from 7,770 to $7,774 \mathrm{ft}$ from $45^{\circ} \mathrm{NE}$ to $42^{\circ} \mathrm{NNE}$ in a tight group of three; next reading is @ 7,790 ft: $23^{\circ} \mathrm{N}$, followed by $13^{\circ} \mathrm{NE} @ 7,792$ and $18^{\circ} \mathrm{N} @ 7,796$ and 7,798 ft. Possible thrust fault @ 7,788 ft, based on GR-Sonic log character, is consistent with dip changes. Three relatively consistent attitudes are recorded from 7,802 to $7,814 \mathrm{ft}: 56^{\circ} \mathrm{W}, 50^{\circ} \mathrm{WSW}$ and $58^{\circ} \mathrm{WSW}$. Dips drop back to $18^{8} \mathrm{NW}$ at $7,884 \mathrm{ft}$. Correction as follows: $\mathrm{a}=(7880-7788) \times \cos 54.66667^{\circ}=53.207 ; \mathrm{b}=$ $(9158-7880) \times \cos 18^{\circ}=1215.45 ; a+b=1268.66$; rounds downward to $1268 \mathrm{ft}$ estimated thickness of Mission Canyon. 
TABLE 1. American Quasar 27-22 Hagenbarth, drilled in SE NW Sec. 27, T. 5 S., R. 9 W. (Lat. $45.37331^{\circ} \mathrm{N}$ Long. $112.70201^{\circ} \mathrm{W}$ ), Beaverhead County, MT. This oil and gas test was completed as a dry hole (D\&A) December 5, 1980, at a total depth of 12,048 ft. Ground surface elevation at the wellsite was $5,410 \mathrm{ft}$. KB elevation, the datum for the borehole logs, was 5,431 ft. A dipmeter arrow plot, available from 1,002-7,918 ft, was used to calculate estimated true thickness of drilled intervals.

Stratigraphic unit
Quaternary valley fill
Upper Cretaceous rock
Frontier Formation
Lower Cretaceous rocks
Blackleaf Formation
Vaughan Member
Flood Member
Kootenai Formation
Pryor Conglomerate Mbr.
Jurassic rocks
Morrison Formation
Ellis Group

\section{Log Tops} feet

0

265

265

$2,350(?)$

$2,350(?)$

2,350(?)

3,080

3,195

3,528

3,603

3,603

3,802

4,075

4,075

4,205

4,610

4,610

4,735

5,140

5,385

5,385

5,385

5,570

5,712

5,728

5,860

5,863

Pennsylvanian rocks

Quadrant Sandstone

Mississippian rocks

Snowcrest Range Group

Conover Ranch Formation

Lombard Limestone

decollement or thrust fault(?)

Kibbey Formation (siltstone)

Madison Group

Mission Canyon Formation thrust fault?

Mission Canyon Formation

Lodgepole Formation

Paine Member

Cottonwood Canyon Mbr.
True thickness [corrected,

Drilled thickness

for interpreted dip]

feet meters

$265 \quad 81$

2,039(?) 621(?)

2,039(?) 621(?)

1,210(?) 369(?)

816(?) 157(?)

705(?) 215(?)

$111 \quad 34$

$394 \quad 120$

$72 \quad 22$

$456 \quad 139$

$192 \quad 59$

$264 \quad 80$

$842 \quad 257$

$124 \quad 38$

387(?) $\quad 118$

$119+\quad 36+$

$383 \quad 117$

$232 \quad 71$

$487 \quad 149$

$487 \quad 149$

$174 \quad 53$

$135 \quad 41$

$15.5 \quad 4.7$

$53 \quad 16$

$\begin{array}{ll}2.8 & 0.85\end{array}$

$36 \quad 11$

$5,902 \quad 658$

$6,560 \quad 3,413$

$6,560 \quad 882$

$6,560 \quad 222$

$6,782 \quad 463$

$7,030 \quad$ NA

197

2,531

1,716

NA

1,370

812

475

3

$\begin{array}{cc}618 & 188 \\ 3,189 & 972 \\ 796 & 243 \\ 211 & 64 \\ 416(?) & 127 \\ & \\ 169 & 52 \\ 2,407(?) & 734(?) \\ 1,632(?) & 497(?) \\ \text { NA } & \text { NA } \\ 1,268(?) & 387(?) \\ 775 & 236 \\ 452 & 138 \\ 2.9 & 0.87\end{array}$


TABLE 1 (continued).

$\begin{array}{lcccc}\text { Devonian rocks } & 9,973 & 645 & 613 & 187 \\ \text { Three Forks Formation } & 9,973 & 155 & 147 & 45 \\ \text { Sappington Member } & 9,973 & 29 & 27.6 & 8.4 \\ \text { Unit 1 (lower Bakken) } & 9,986 & (16) & (15) & 5 \\ \text { Trident Shale Member } & 10,002 & 28 & 26.6 & 8 \\ \text { Logan Gulch Member } & 10,030 & 98 & 93 & 28 \\ \text { Jefferson Dolomite } & 10,128 & 490 & 466 & 142 \\ \text { Cambrian rocks } & 10,618 & 1,215 & 1,156 & 352 \\ \text { Pilgrim Dolomite } & 10,618 & 302 & 287 & 88 \\ \text { Park Shale } & 10,920 & 122 & 116 & 35 \\ \text { Meagher Dolomite } & 11,042 & 545 & 518 & 158 \\ \text { Wolsey Shale } & 11,587 & 163 & 155 & 47 \\ \text { Flathead Sandstone } & 11,750 & 83 & 79(?) & 24(?) \\ \text { Precambrian? sedimentary } & & & & \\ \text { rocks (Belt?) } & 11,833 & 76(?) & 72(?) & 22(?) \\ \text { Precambrian metamorphic } & & & & \\ \text { rocks } & 11,909 & & & \end{array}$




\section{METHODS}

Formation and member tops, in the American Quasar 27-22 Hagenbarth drillhole (table 1), are based primarily on my interpretation of the borehole compensated sonic and gamma ray (BHC/GR) log, in conjunction with the compensated neutron-formation density (FDC/CNL) log and log of lithology of returned drill cuttings, commonly known as a mudlog. These data were then compared with those of other drillholes from southwest Montana (Perry and others, 1981; Perry, 1986) as well as descriptions of stratigraphic units by Lowell (1949, 1963), Pecora (1981), and Hildreth (1981). I calculated formation thickness from drilled intervals, picked on the BHC/GR log, on the basis of publicly released dipmeter arrow plots (dip azimuth vs. dip magnitude) for the drill-hole interval 1,002 to 7,918 ft. I used an eyeball average for consistent (more than three) nearby readings, eliminating data scatter that is likely due to fractures, cross-stratification, or miscorrelation of resistivity curves. As always, the reported depths of drill cuttings need to be adjusted to those of lithology changes indicated by the geophysical borehole log curves (table 1).

One- to 5-pound, cloth-bagged samples of borehole cuttings were obtained from the operator for $10 \mathrm{ft}$ intervals from 9,820-10,270 ft, from the lower Lodgepole through upper Jefferson Formations. Cuttings from the intervals 9,820-50, 9,950-60 and 9,990-10,000 ft were processed for conodonts by C. A. Sandberg. Conodont elements and fragments of elements from all three intervals indicate a CAI of 3 (C.A. Sandberg, 1997, written communication). The bagged cuttings appear to be about $30 \mathrm{ft}$ low at the base of the Lodgepole $(9,973 \mathrm{ft}$, table 1$)$ with respect to the BHC/GR log: well cuttings from the depth interval 9,990-10,000 ft which yielded Kinderhookian (basal Mississippian as well as basal Lodgepole) conodonts, reported by C.A. Sandberg (1997, written communication). Lag (depth of cuttings vs. geophysical borehole depths) appears to vary, as black shale of the Cottonwood Canyon? Member of the Lodgepole Limestone (upper Bakken equivalent?) first appears in the cuttings in the interval $9,980-90 \mathrm{ft}$ (10\% shale); the gamma radiation marker on the gamma ray-sonic log places the Cottonwood Canyon at 9,970-9,973 ft. The proportion of black shale to limestone climbs to $95 \%$ black shale in the interval 10,000-10 ft and is approximately $90 \%$ in the interval $10,010-20 \mathrm{ft}$. The strong gamma radiation marker for the basal black shale of the Sappington Member of the Three Forks (lower Bakken equivalent?) is from 9,986-10,002 ft (table 1) based on geophysical borehole logs. Here the lag appears to be of the order of 14 to $18 \mathrm{ft}$, consistent with the organic carbon values reported (table 2). The usual downhole contamination from borehole cavings complicates the story; shales cave much more readily than carbonate rocks.

The interval 9,820-10,100 ft, which spanned expected Lower Mississippian through Upper Devonian potential hydrocarbon source rocks, was analyzed by Rock-Eval pyrolysis (Jerry Clayton, 1981, written communication). Organic carbon (TOC) determinations of these 26 samples were conducted by Rinehart Laboratories, Inc. Both sets of results are summarized in table 2. Rock-Eval pyrolysis is the controlled heating of a rock sample under dry conditions. It is currently the most common laboratory screening technique in hydrocarbon source rock evaluation (Bordenave and others, 1993) and was conducted on 26 samples in conjunction with the present study (table 2). Tmax is the temperature in ${ }^{\circ} \mathrm{C}$ (degrees Celsius) recorded for the maximum generation of hydrocarbons from kerogen, the insoluble organic material in the cuttings, during the artificial maturation caused by dry pyrolysis. It is a measure of thermal maturity. The high-temperature end of the oil window in source rocks occurs at a Tmax of about $460^{\circ} \mathrm{C}$ (Tissot and Welte, 1978, p. 454, fig. V.1.16). More recently, Bordenave and others (1993, fig. 2-17) showed that the oil and gas window varies slightly for different types of organic matter. Highly mature Type III organic matter can give Rock-Eval TOC values as much as 48 percent lower than actual (Bordenave and others, 1993, table $2-4$ ), because $600^{\circ}$ combustion does not completely oxidize such material. The boldface values of Tmax (table 2) for samples containing more than $0.9 \%$ TOC are believed 


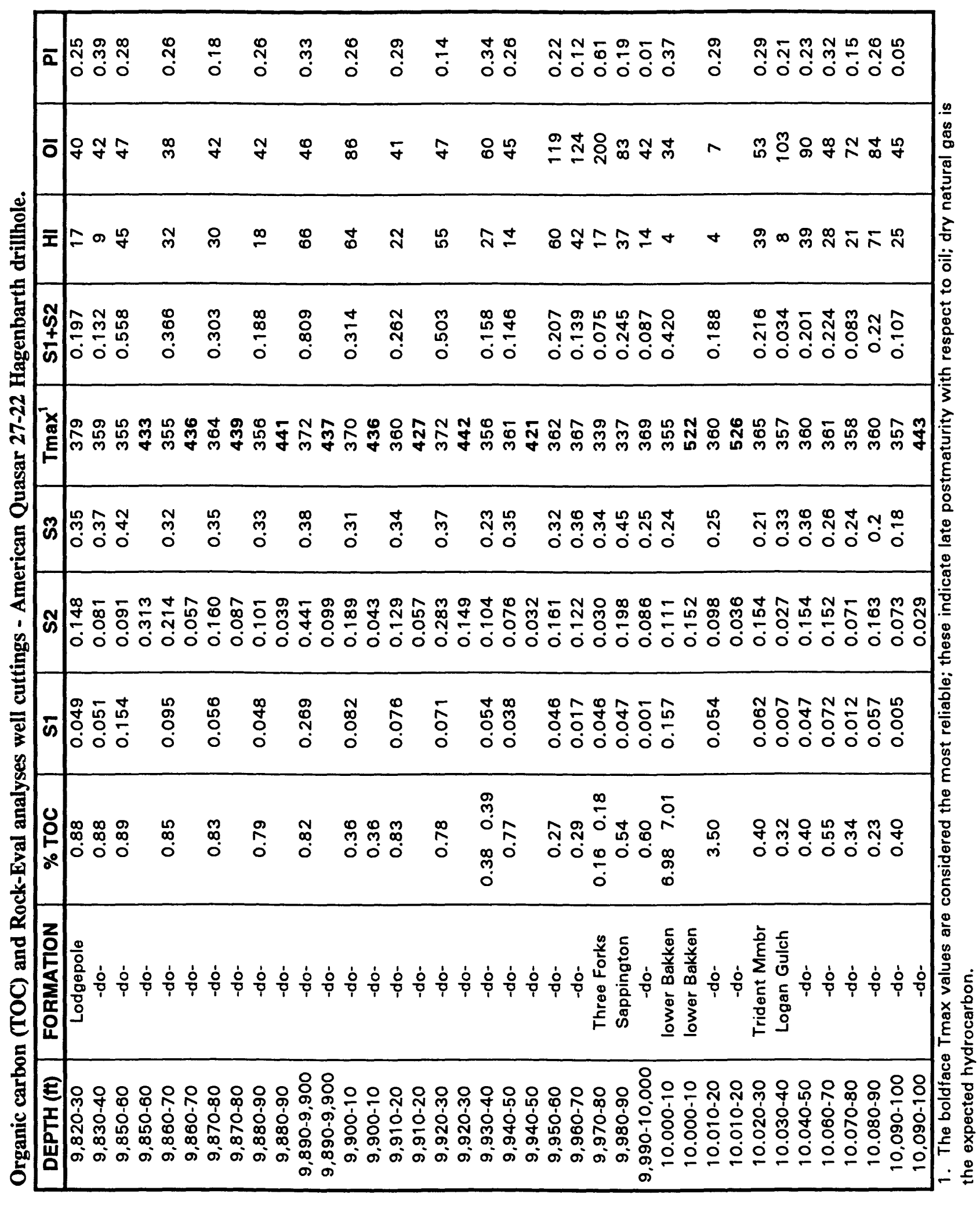


the most reliable. These are well above the oil window. The $S_{1}$ peak (table 2 ) is a measure of hydrocarbons that exist in a rock sample and "can be used as a tool to detect migrated hydrocarbons" (Bordenave and others, 1993, p. 241). The $\mathbf{S}_{2}$ peak represents hydrocarbons produced by heating of kerogen (Types I, II III). It "gives a reasonable evaluation of the current [hydrocarbon generation] potential of a rock sample"; 70-80 percent of Type I, 45-50 percent of Type II, and only 10-25 percent of Type III kerogen are transformed into hydrocarbons during pyrolysis (Bordenave and others, 1993, p. 242). Rocks with $S_{2}<4 \mathrm{mg} / \mathrm{g}$ of sample have low or no hydrocarbon generation potential; $S_{2}$ between 4 and 8 indicates fair potential (Bordenave and others, 1993, p. 260). None of our samples had $\mathrm{S}_{2}$ values as high as 0.5 (table 2). The $S_{3}$ peak is a measure of carbon dioxide generated in the sample during pyrolysis of oxygen-bearing organic compounds. It is recorded below $400^{\circ} \mathrm{C}$ because of thermal decomposition of some carbonates and other poorly crystallized inorganic crystalline materials occurs at higher temperatures. The accuracy of this peak is low for rocks with low organic content (TOC $<0.5$ percent, especially those containing a large amount of siderite), affecting the oxygen index [OI], computed from $\mathrm{S}_{3} / \mathrm{TOC}$. The hydrogen index [HI], computed from $\mathrm{S}_{2}$ /TOC, correlates well with H/C [atomic] ratios of kerogen. HI vs Ol diagrams are used in classifying Types I, II, and III kerogen (Bordenave and others, 1993, p. 251). PI (table 2), the production index, is the $S_{1} /\left(S_{1}+S_{2}\right)$ ratio, which increases mainly due to cracking of the kerogen (Bordenave and others, 1993, p. 252). Values lower than 0.05 indicate immature kerogens; 0.6 or higher values indicate almost all hydrocarbons have formed (Bordenave and others, 1993, p. 252). The low values of both $S_{1}$ and $S_{2}$ obtained for our samples (table 2) render the PI results suspect.

\section{STRATIGRAPHIC DISCUSSION}

Mesozoic rocks. Although thicknesses of post-Triassic rocks in the Hagenbarth drillhole were not readily comparable with those of the nearby Armstead anticline and Blacktail Mountains to the south (fig. 2 and table 3), no obvious thrust faulting was observed from the borehole data above 4,610 ft. The Cretaceous Frontier/Blackleaf contact is obscure. My pick (at about 2,350 ft) is based on a downward increase in abundance of volcaniclastic material, assigned to the Vaughan Member of the Blackleaf Formation, and a downward decrease in gray-green shale and siltstone, typical of the lower Frontier. The underlying Flood Member of the Blackleaf contains interbedded black shale, light-gray siltstone, and sandstone. The underlying Kootenai has a dip-corrected thickness of $394 \mathrm{ft}$, with the distinctive Pryor (Cloverly) Conglomerate Member at the base (fig. 3). Jurassic rocks have a dip-corrected thickness of about $472 \mathrm{ft}$ (table 1). Repetition of lithologies and log characteristics occurred in the Triassic interval, indicating that a thrust fault was probably encountered at a log depth of $4,610 \mathrm{ft}$. Average dip appears to increase from $17^{\circ} \mathrm{NW}$ to $19^{\circ} \mathrm{NW}$ at this depth (see explanation of table 1); $530 \mathrm{ft}$ of section is repeated. The interval assigned to the Triassic (table 1) is estimated to have been originally slightly more than $840 \mathrm{ft}$ thick, close to the 700 $800 \mathrm{ft}$ thickness given by Lowell (1949). On the surface, in the Blacktail Mountains to the south, the entire Triassic section is placed in the Dinwoody Formation (Pecora, 1981). However the Triassic sequence encountered in the Hagenbarth drillhole appears more like that observed south and east of Lima (Perry, 1986): an upper limestone (Thaynes), a thick middle sequence of brick-red shale, light-red calcareous siltstone and minor limestone (Woodside), and a lower gray-brown to medium- to dark-gray limestone (Dinwoody). Regionally the Triassic sequence thickens southward in outcrop, from $430 \mathrm{ft}$ in the Blacktail Mountains to 1,315 $\mathrm{ft}$ in the Blacktail Road area in the Snowcrest Range (table 3). However, undivided Triassic rocks are also about $430 \mathrm{ft}$ thick near Melrose north of the drillhole site (J.M. O'Neill, 1997, written communication). The dip-corrected Triassic thickness and likely presence of both Thaynes and Woodside Formations in the Hagenbarth drillhole appears 


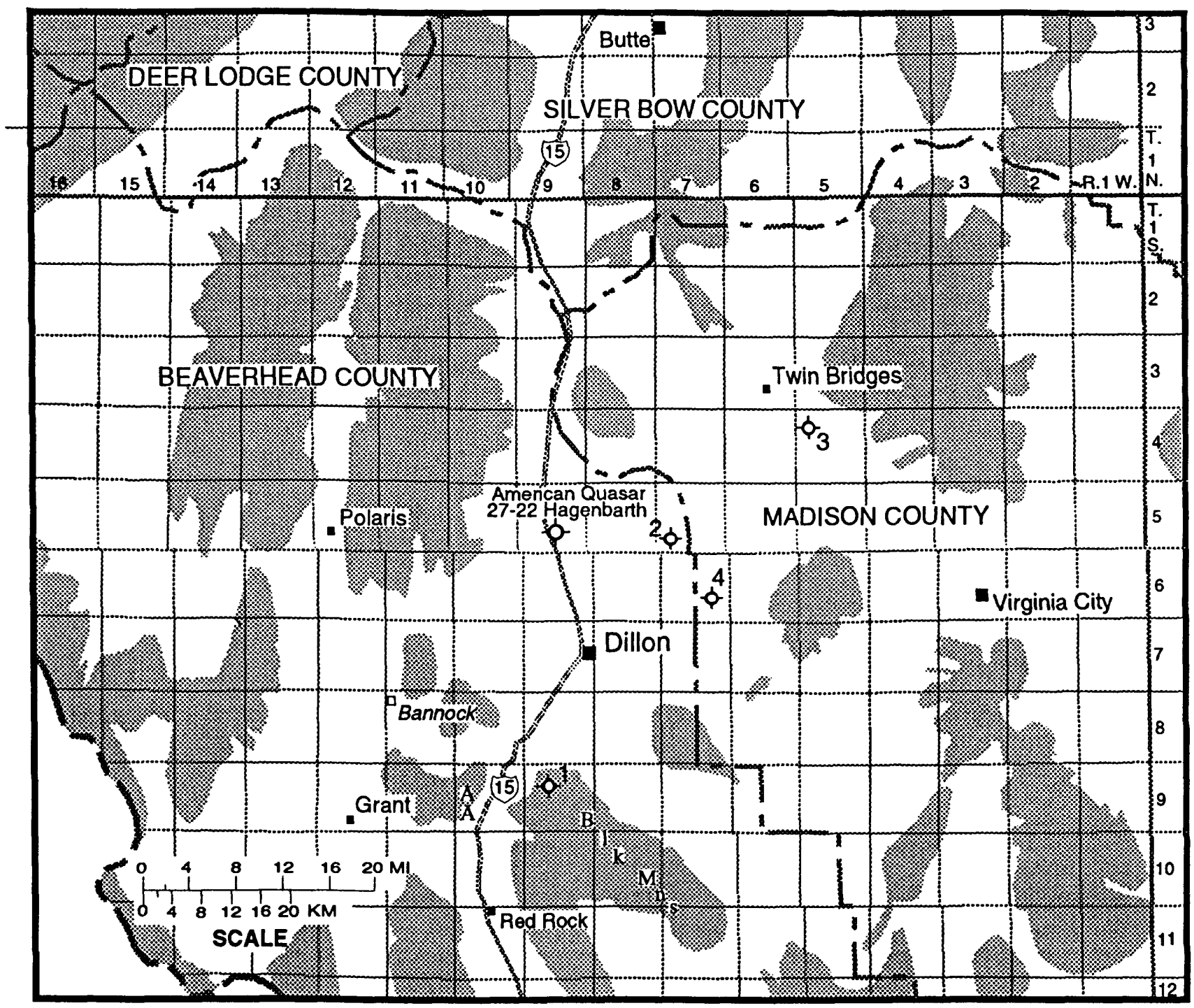

Figure 2. Index map of a portion of southwestern Montana showing the location of the Hagenbarth drillhole and nearby localities: AA - Armstead anticline; Blk Mns - Blacktail Mountains. Highlands are shaded. Drillhole 1 is American Quasar 9-1 May-Federal; 2 is American Quasar Petroleum 29-1 Rebish; 3 is North American Resources 3-8-4-5; 4 is North American Resources 7-23 State. 


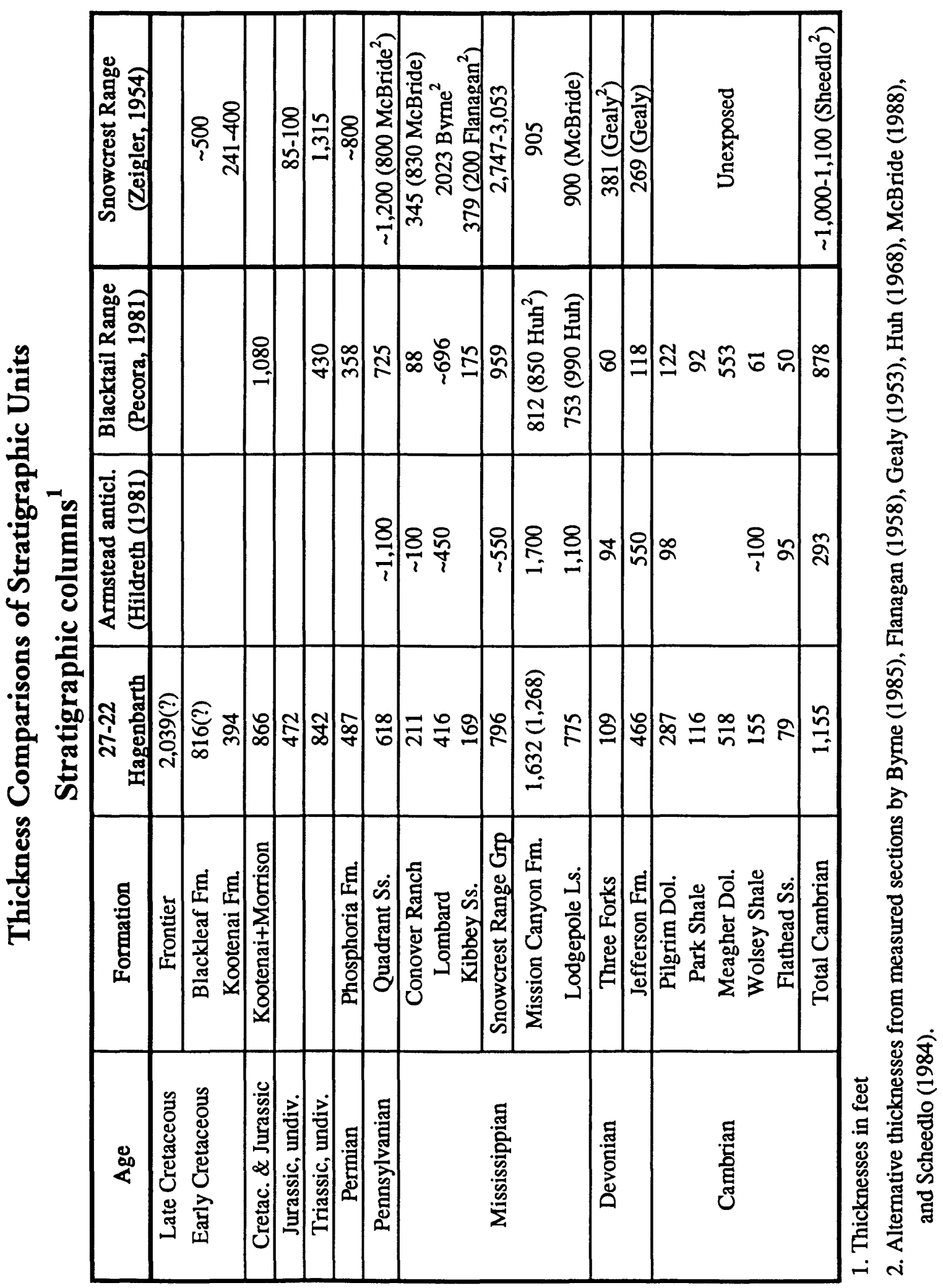

$\dot{0}$
$\frac{\Phi}{0}$
$\stackrel{0}{\circ}$ 


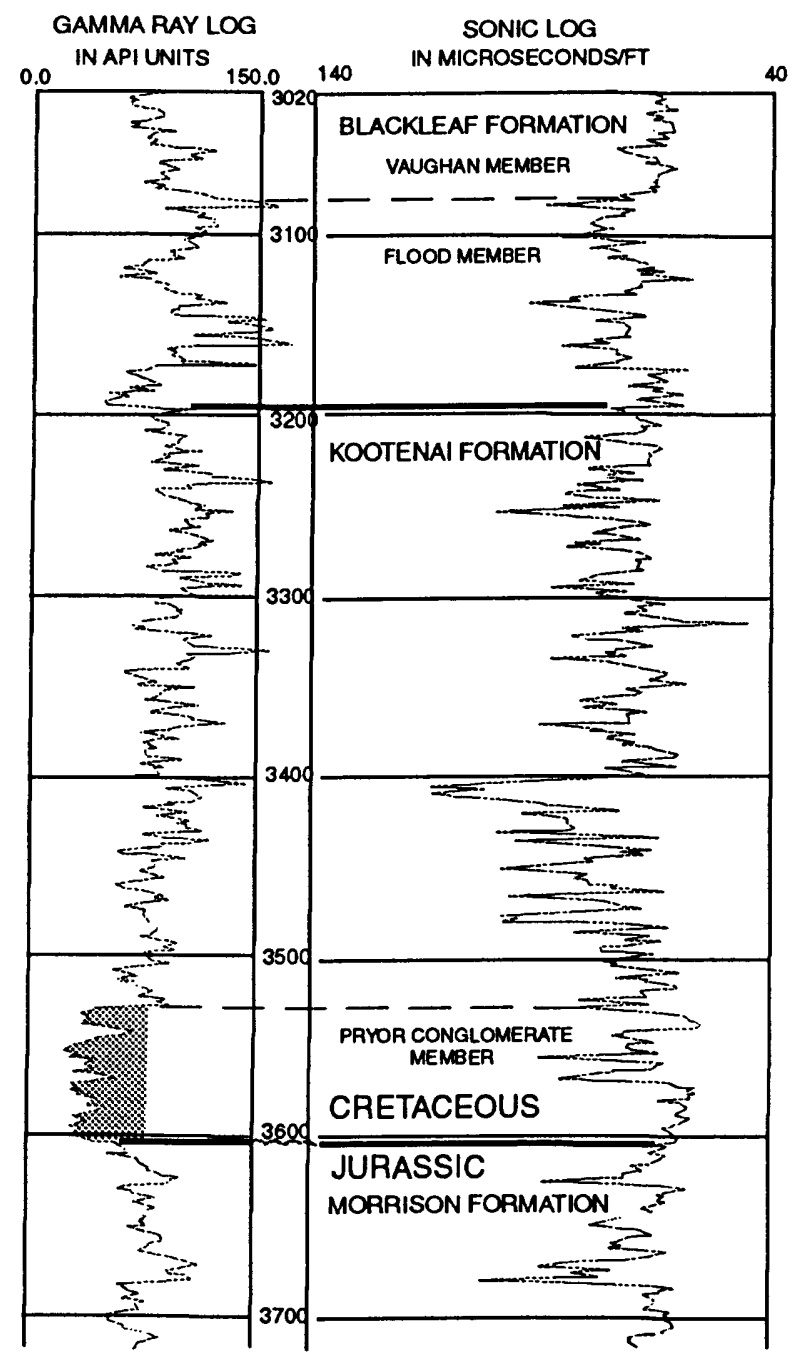

Figure 3. Lower Cretaceous and probable Cretaceous/Jurassic boundary section of BHC/GR log, American Quasar 27-22 Hagenbarth drillhole. 
anomalous, based on both the above references and Peterson (1985, fig.15). Possibly, dips get very steep close to the thrust fault, so that my dip corrections may be insufficient; possibly smaller contraction faults exist near the larger thrust fault at 4,610 ft log depth. However, the dip-corrected thickness of Woodside(?) turned out the same both above and below the thrust, $405 \mathrm{ft}$, suggesting that the total Triassic thickness in the area of the drillhole may indeed exceed $800 \mathrm{ft}$. Paull and others (1989) report the presence of Thaynes in their nearby incomplete Birch Creek section (SW 1/4, sec. 24, T. 5 S., R. 10 W.), where Moritz (1950) earlier reported a total Triassic thickness of $885 \mathrm{ft}$.

Upper Paleozoic rocks. The dip-corrected thickness of Permian (487 ft), Pennsylvanian (618 ft), and Mississippian strata (3,635 ft) in the Hagenbarth drillhole (table 1$)$ is more consistent than that of the drilled Triassic sequence with reported thicknesses in the region (table 3). The Mississippian assignment of the Conover Ranch (formerly Amsden Formation) follows Wardlaw and Pecora (1985).

The Permian Phosphoria Formation is comprised of from top downward, $142 \mathrm{ft}$ of Shedhom Sandstone Member, underlain by about $16 \mathrm{ft}$ of the Tosi Chert Member. The underlying Retort Phosphatic Shale Member, is about $53 \mathrm{ft}$ thick, and the Meade Peak, $23 \mathrm{ft}$ farther downhole, is slightly less than $3 \mathrm{ft}$ thick based on gamma ray signature on the BCS/GR-log. The Retort has excellent oil-source-rock potential to the south, in the Blacktail Mountains (Claypool and others, 1978). The basal Grandeur Member (36 $\mathrm{ft}$ thick, table 1 ) is predominately dolomite.

The BCS/GR-log base of continuous sandstone in the Pennsylvanian Quadrant Sandstone occurs at 6,520 $\mathrm{ft}$ (based on abrupt increase downward to carbonate velocities at this depth). The interval 6,520-40 ft appears to be predominately dolomite; then lower interval travel times versus low gamma ray response strongly suggests that the basal $20 \mathrm{ft}$ of Quadrant $(6,540-6,560 \mathrm{ft})$ is again sandstone. Drill cuttings show considerable lag here (about $50 \mathrm{ft}$ ) with the mudlog base of the Quadrant about 6,610 ft. Dolomite predominates in the cuttings from 6,700 to $6,850 \mathrm{ft}$, described as silty to argillaceous, with red to dark-gray shale logged from about 6,600 to $6,750 \mathrm{ft}$, comprising $50 \%$ of the cuttings from $6,680-6,700 \mathrm{ft}$ on the mudlog. Based primarily on the BCS/GR log, I interpret the interval 6,560-6,782 $\mathrm{ft}$ as Conover Ranch Formation (table 1), formerly the "Alaska Bench" of E. K. Maughan (oral communication, 1982). The interval from 6,782 to $7,245 \mathrm{ft}$ is limestone dominated, with abundant interbedded shale indicated on the gamma ray-sonic log. The limestone is predominantly dark gray to tan, fine grained, and dolomitic in part, according to the mudlog. Velocities are generally higher in this interval than either directly above or below. The basal $150 \mathrm{ft}$ is virtually continuous limestone as in the basal Lombard Formation in the Snowcrest Range to the south. I classify this entire unit $(6,782-7,245 \mathrm{ft})$ as Lombard Limestone.

At $7,300 \mathrm{ft}$ the mudlog lags the gamma ray-sonic log by about $50 \mathrm{ft}$. The interval $7,245-7,442 \mathrm{ft}$ is predominantly orange siltstone with occasional sandstone and sandy dolostone of the Kibbey Formation as exposed in the Blacktail Mountains and Snowcrest Range (Pecora, 1981; Perry and others, 1988). The interval 6,560-7,442 ft comprises the Snowcrest Range Group of Wardlaw and Pecora (1985). My calculated thicknesses are 796 $\mathrm{ft}$ for the group and $211 \mathrm{ft}$ for the Conover Ranch, $416 \mathrm{ft}$ for the Lombard, and $169 \mathrm{ft}$ for the Kibbey (table 1). Based on the regional nature of this interval, tightly folded on the Armstead anticline, and imbricately thrusted in the Blacktail and Tendoy Mountains, it is unwise to trust these computed thicknesses. Additionally, the regional seismic section (Lopez and Schmidt, 1985 ) requires a decollement in this interval, close to and above the Mission Canyon Formation, possibly at about $7,030 \mathrm{ft}$, based on comparison of the BCS/GR and other geophysical borehole logs. 
The Mission Canyon may be partly repeated by thrusting, with a thrust fault encountered at about $7,788 \mathrm{ft}$ repeating the upper $346 \mathrm{ft}$ drilled interval of Mission Canyon (see footnote 2 to the explanation of table 1). According to descriptions of cuttings on the mudlog, the Mission Canyon is a medium- to dark-gray partly dolomitic micritic limestone which contains abundant calcite-filled fractures. Below $9,000 \mathrm{ft}$, fossil fragments are logged on the mudlog; I used the gamma ray log break at 9,158 as the top of the Lodgepole (table 1 and fig. 4), but the upper member of the Lodgepole - the Woodhurst Member - is very fossiliferous on the Armstead anticline and in the Highland Mountains northeast of the drillsite. The contact may thus be higher than suggested by the gamma ray log. Below 9,500 $\mathrm{ft}$, the Lodgepole becomes predominantly very dark-gray, very fine-grained, and not visibly fossiliferous limestone, typical lithology of the Paine Member of the Lodgepole, as observed on the east flank of the Armstead anticline. At the base of the Paine Member of the Lodgepole, $9,970 \mathrm{ft}$ by BCS/GR log response, the mudlog lags the gamma ray-sonic log by about $30 \mathrm{ft}$. Thus the reported depths of cuttings analyzed both for conodonts, TOC, and RockEval (table 2) are off BCS/GR log depth by this amount near the base of the Mississippian. The Cottonwood Canyon Member of the Lodgepole, the "Upper Bakken" equivalent of the oil and gas industry, is represented by an abrupt increase in natural gamma radiation from 9,970-9,973 $\mathrm{ft}$ on the BCS/GR log (fig.4). Total thickness of Mississippian rocks penetrated by the Hagenbarth drillhole is about $2,840 \mathrm{ft}$.

Lower Paleozoic rocks. The Devonian-Mississippian contact is placed at 9,973 ft. All three members of the directly underlying Devonian Three Forks Formation can be recognized by BCS/GR log response (fig.4), although the typical green shale of the Trident member was not recorded on the mudlog. The Three Forks appears to be about $147 \mathrm{ft}$ thick in the Hagenbarth drillhole. The gamma ray intense black shale of unit 1 (lower Bakken) at the base of the Sappington Member is $15 \mathrm{ft}$ thick (table 1 and fig. 4). The recorded TOC of 3.5 to $7 \%$ from this interval (table 2) may be low, due to uphole contamination of the cuttings analyzed. First appearance of tan to light-brown Logan Gulch dolostone in the cuttings at $10,060 \mathrm{ft}$ versus the BCS/GR log top at $10,030 \mathrm{ft}$, indicates that the mudlog tops are $30 \mathrm{ft}$ low with respect to the BCS/GR log, the same lag found at the base of the Mississippian.

The Jefferson Formation, $466 \mathrm{ft}$ thick in the Hagenbarth drillhole, is primarily light- to medium- and dark-gray dolostone, microcrystalline to finely crystalline, with traces of anhydrite. Medium-gray shale in this interval of the mudlog may represent cavings.

The top of the Cambrian was encountered at a depth of about $10,618 \mathrm{ft}$ and is marked by transition to dark gray-brown laminated dolostone. The uppermost Cambrian unit, about 287 feet thick in the Hagenbarth drillhole, is assigned to the Pilgrim Dolomite (after Lowell, 1965, p.1; Pecora, 1981, p.19), although Sandberg (1997, written communication) identified this as Red Lion Formation at an outcrop 12 miles to the northeast. Lag in cuttings vs. BCS/GR log depths is only about $10 \mathrm{ft}$ at the Pilgrim/Park Shale contact. The Park Shale, described as green to gray green and slightly silty on the mudlog, has a calculated thickness of $116 \mathrm{ft}$. The underlying Meagher Dolomite, about $518 \mathrm{ft}$ thick, consists of predominantly dark-brown to dark gray-brown medium-crystalline to microcrystalline dolostone.

The BCS/GR log top of the Wolsey Shale occurs at a depth of $11,587 \mathrm{ft}$. Here, there is little if any sample lag as indicated by the mudlog top of the Wolsey at about $11,580 \mathrm{ft}$. The Wolsey is described as a green waxy to silty shale with interbedded light- to mediumgreen sandy siltstone. The Wolsey is calculated to be about $155 \mathrm{ft}$ thick. The underlying Flathead Sandstone is $79($ ?) $\mathrm{ft}$ thick with a sharp base on the BCS/GR log at 11,833 ft. Beneath the Flathead is an approximately 72-ft-thick interval logged as quartzitic sandstone, white to pink, very fine to coarse grained, the base of which appears to be at about 11,909 ft on the BCS/GR log. The mudlog places the base of this sandstone at 11,960 ft. This interval 


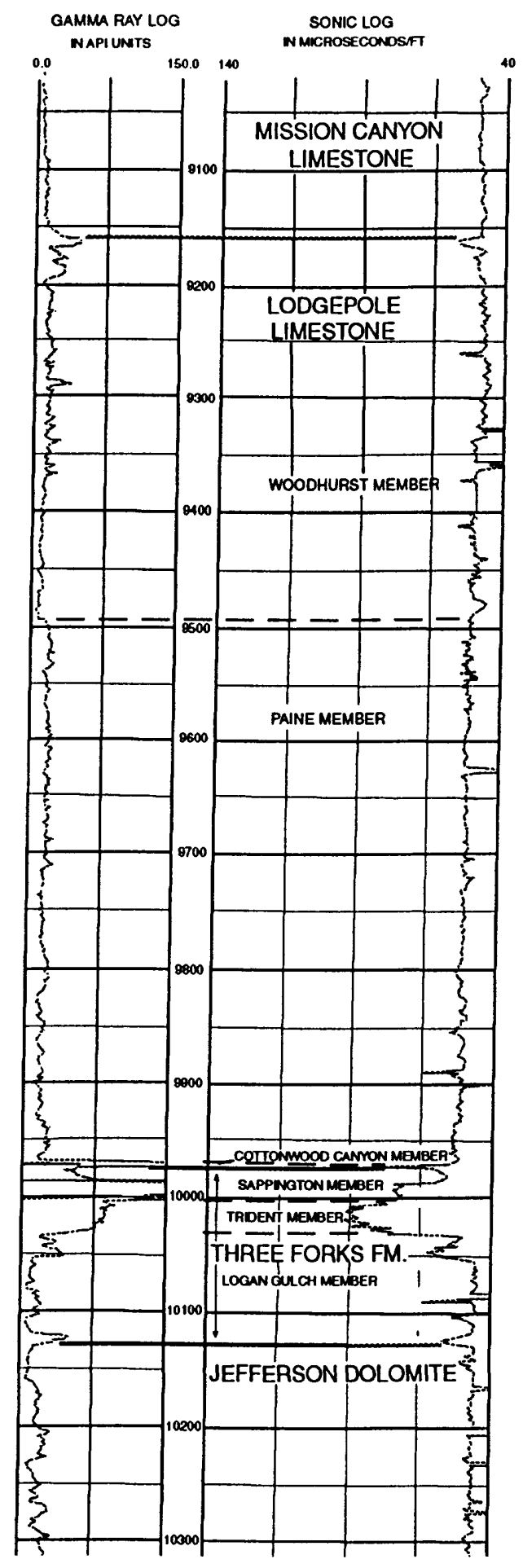

Figure 4. Lower Mississippian and Upper Devonian sections of BHC/GR log, American Quasar 27-22 Hagenbarth drillhole. 
is interpreted as possibly a pocket of or near wedge edge of Proterozoic Belt sandstone. Beneath this sandstone the mudlog lists "granite/schist", undoubtedly high-grade metamorphic rocks. Pearson (1996) found $722 \mathrm{ft}$ of possibly equivalent Middle Proterozoic Belt Supergroup, primarily "ferruginous, argillaceous, micaceous, feldspathic quartzite; red and green sandy and silty argillite; and thick-bedded coarse-grained to very coarse-grained feldspathic quartzite" in core from a shallow drillhole in the Argenta mining district about 20 $\mathrm{km}$ northwest of Dillon, Montana.

\section{THERMAL MATURATION AND HYDROCARBON POTENTIAL}

Thermal maturity indicators obtained from Lower Mississippian and Upper Devonian cuttings from the Hagenbarth drillhole include conodont $\mathrm{CAl}$, vitrinite reflectance, TAI, and Rock-Eval pyrolysis results. Conodont elements and fragments of elements were obtained from cuttings from the intervals 9,820-50, 9,950-60 and 9,990-10,000 ft; all three intervals indicate a CAl of 3 (C.A. Sandberg, 1997, written communication), postmature with respect to oil (fig. 5, Perry and others, 1983). Cuttings from the interval with the highest reported TOC, $10,000-10,100 \mathrm{ft}$, yielded ordered vitrinite reflectance values ranging from 1.72 to 2.82 ; the median reflectance of the 57 ordered reflectance values obtained was 2.39; the mean reflectance was 2.36 with a standard deviation of 0.24 (Mark J. Pawlewicz, written communication, 1981), indicating late postmaturity with respect to oil (fig. 5, Perry and others, 1983), a slightly higher thermal maturity than indicated by the conodont CAl. Cuttings from the same interval were processed for kerogen color and TAl by A.H. Love. The dark brown kerogen color and TAl of 4 obtained, are consistent with the vitrinite results. Tmax results from Rock-Eval pyrolysis (in boldface for higher than 1\% TOC samples, table 2) reported by J.L. Clayton (written communication, 1981) also indicate late postmaturity with respect to oil. Low $\mathrm{S}_{2}$ results (table 2 ) indicate no or very low hydrocarbon generating capacity.

Unfortunately, no Permian cuttings were acquired for source rock analysis. Samples of the Retort (nos. 9-10, Claypool and others, 1978, table 2) from sec. 23, T. 9 S., R. 9 W., in the Blacktail Mountains to the south, ranged from $11.9 \%$ to $13.3 \%$ organic carbon and contained 16.8 to 18.9 parts/thousand extractable bitumen, excellent oil source rocks. A sample from the Pioneer Mountains to the west (no. 12, Claypool and others, 1978, table 2, sec. 3, T. 6 S., R. 11 W.), contained only $0.5 \%$ organic carbon and was supermature with respect to liquid hydrocarbon generation. By extrapolation, the Phosphoria in the Hagenbarth drillhole may also be supermature, but likely generated liquid hydrocarbons during Cretaceous maximum burial and high heat flow associated with magmatic activity.

\section{CONCLUSIONS}

The Hagenbarth drillhole appears to have encountered about $72 \mathrm{ft}$ of Middle Proterozoic Belt quartzite beneath the basal Phanerozoic Flathead Sandstone; no Belt rocks are present on the Armstead anticline or Blacktail Mountains (fig. 2). Pearson (1996) shows that Belt rocks thicken rapidly to the north and west of the Hagenbarth drillhole. The encounter in the drillhole is the farthest southeast that Middle Proterozoic rocks have been reported.

The Hagenbarth drillhole provides critical data on the thickness and character of Paleozoic rocks north of Dillon. Cambrian strata are thicker than to the south and west (table 3 ) in agreement with Peterson (1985). Ordovician through Middle Devonian strata are absent, also in agreement with Peterson (1985). Upper Devonian through lowermost Mississippian Bakkan-equivalent strata contain as much as $7 \%$ organic carbon and are supermature with respect to liquid hydrocarbons. The Lower Mississippian Madison Group is probably slightly more than $2,400 \mathrm{ft}$ thick, apparently somewhat thinner than on the Armstead 
anticline, but thicker than to the southeast (fig. 2; table 3). The presence of Upper Paleozoic Snowcrest Range Group (SRG) at this latitude is in agreement with Peterson (1985). The Kibbey Formation at the base of the SRG is a distinctive orange siltstone, about $170 \mathrm{ft}$ thick in the drillhole, not significantly different than reported by Pecora (1981) in the Blacktail Mountains. The Pennsylvania Quadrant Sandstone is more than $600 \mathrm{ft}$ thick and represents a potential hydrocarbon reservoir rock. The overlying Phosphoria Formation is about $487 \mathrm{ft}$ thick, considerably thicker than the approximately $100 \mathrm{ft}$ shown by Peterson (1985, fig. 14). The Phosphoria contains two black shale members, the Retort about $53 \mathrm{ft}$ thick and the underlying Meade Peak, slightly less than $3 \mathrm{ft}$ thick based on gamma ray signature.

About $842 \mathrm{ft}$ of Triassic and $456 \mathrm{ft}$ of Jurassic rocks are present in the Hagenbarth drillhole. The Triassic sequence is similar to that farther south as discussed above, such that Thaynes, Woodside, and Dinwoodie Formations are all three present. Thickness encountered is similar to that measured by Moritz (1950), nearby, but very different than estimated or measured by others as discussed at length above. The Jurassic sequence encountered consists of about $264 \mathrm{ft}$ of Ellis Group and $192 \mathrm{ft}$ of overlying Morrison Formation. If correct, this aggregate thickness of $456 \mathrm{ft}$ of Jurassic rocks, far in excess of the less than $100 \mathrm{ft}$ reported by Peterson (1985, fig. 16), requires rethinking the presence, location or size of his Jurassic 'Boulder high'. The overlying Lower Cretaceous sequence is subdivided into the Kootenai Formation, about $394 \mathrm{ft}$ thick, and overlying Blackleaf Formation, about $816 \mathrm{ft}$ thick, as discussed above. More than 2,000 ft of Upper Cretaceous Frontier Formation are present in the Hagenbarth drillhole; this siliciclastic formation extends nearly to the surface. Only $265 \mathrm{ft}$ of Quaternary valley fill is present at the drill site. The broad Quatemary valley here is not underlain by Tertiary rocks. 


\section{REFERENCES}

Bordenave, M.L., Espitalié, J., Leplat, P., Oudin, J.L., and Vandenbroucke, M., 1993, Screening techniques for source rock evaluation, in Bordenave, M.L., ed., Applied petroleum geochemistry: Éditions Technip., 27 rue Ginoux 75015, Paris, p. 217-278.

Brandon, W.C., 1984, An origin for the McCartney's Mountain salient of the southwestem Montana fold and thrust belt: University of Montana, unpublished M.S. thesis, Missoula,128 p.

Brumbaugh, D. S., 1973, Structural geology of the complexly deformed Big Hole River area, Madison, Beaverhead, and Silverbow Counties, Montana: Indiana University, unpublished $\mathrm{Ph}$. D. dissertation, Bloomington, $96 \mathrm{p}$.

Brumbaugh, D. S., and Dresser, H. W., 1976, Exposed step in Laramide thrust fault, Southwest Montana: AAPG Bull., v. 60, no. 12, p. 2142-2149.

Brumbaugh, D. S., and Hendrix, T. E., 1981, The McCarthy Mountain structural salient, southwestern Montana, in Tucker, T.E., ed., Southwest Montana: Montana Geol. Soc., 1981 Field Conference Guidebook, p. 201-209.

Byme, D.J., 1985, Stratigraphy and depositional history of the upper Mississippian Big Snowy Formation in the Snowcrest Range, southwestem Montana: Oregon State University, unpublished M.S. thesis, Corvalis, $417 \mathrm{p}$.

Flanagan, W.H., 1958, Geology of the southem part of the Snowcrest Range, Beaverhead County, Montana: Indiana University, unpublished M.A. thesis, Bloomington, 41 p.

Gealy, W.J., 1953, Geology of the Antone Peak Quadrangle, southwestem Montana: Harvard University, unpublished Ph. D. dissertation, Cambridge, Massachusetts, $143 \mathrm{p}$.

Harlan, S.S., Geissman, J.W., Lageson, D.R., and Snee, L.W., 1988, Paleomagnetic and isotopic dating of thrust-belt deformation along the eastem edge of the Helena salient, northem Crazy Mountains basin, Montana: Geological Society of America Bulletin, v. 100, p. 492-499.

Hildreth, G.D., 1981, The bedrock geology and stratigraphy of the Mississippian and early Pennsylvanian rocks of the southeast flank, Amstead anticline, Beaverhead County, Montana: Oregon State University, unpublished M.S. thesis, Corvalis, 144 p.

Huh, O. K., Jr., 1967, Mississippian system across the Wasatch Line, east-central Idaho, extreme southwestem Montana: Montana Geol. Soc., 18th Ann. Field Conf. Guidebook, p. 31-62.

Lowell, W. R., 1949, Geology of the Small Hom Canyon, Daly's Spur, Cedar Creek, and Dell areas, southwestem Montana: U. S. Geol. Survey Open-File Report 49-2, 7 p.

Lowell, W. R., 1965, Geologic map of the Bannack-Grayling area, Beaverhead County, Montana: U. S. Geol. Survey Misc. Geol. Inv. Map 1-433, scale 1:31,680. 
Lopez, D.A., and Schmidt, C.J., 1985, Seismic profile across the leading edge of the fold and thrust belt in southwestem Montana, in Gries, R.R., and Dyer, R.C., eds., Seismic exploration in the Rocky Mountain region: Rocky Mountain Association of Geologists and Denver Geophysical Society, p. 45-50.

McBride, B.C., 1988, Geometry and kinematics of the central Snowcrest Range: A Rocky Mountain foreland uplift in southwestem Montana: Westem Michigan University, unpublished M.S.thesis, Kalamazoo, 267 p.

Moritz, C. A., 1951, Triassic and Jurassic stratigraphy of southwestem Montana: AAPG Bull., v. 35, no. 8, p. 1781-1814.

Paull, R.A., Paull, R.K., and Kraemer, B.R., 1989, Depositional history of Lower Triassic rocks in southwestem Montana and adjacent parts of Wyoming and Idaho, in French, D.E., and Grabb, R.F., Geologic resources of Montana: Montana Geological Society 1989 Field Conference Guidebook: Montana Centennial Edition, v. 1, p. 69-90.

Pecora, W. C., 1981, Bedrock geology of the Blacktail Mountains, southwestem Montana: Wesleyan University, unpublished MS thesis, Middletown, Connecticut, 203 p.

Pecora, W. C., 1987, Geologic map of frontal fold and thrust zone in the Blacktail Mountains, Beaverhead County, Montana: U.S. Geological Survey Open-File Report OF-87-0079, scale 1:24,000.

Perry, W. J., Jr., 1986, Critical deep drillholes and indicated Paleozoic paleontologic features north of the Snake River downwarp in southem Beaverhead County, Montana, and adjacent Idaho: U. S. Geol. Survey Open-File Report 86-413, 16 p.

Perry, W. J., Jr., Ryder, R. T., and Maughan, E. K., 1981, The southem part of the southwest Montana thrust belt, in Tucker, T.E., ed., Southwest Montana: Montana Geol. Soc., 1981 Field Conference Guidebook, p. 261-273.

Perry, W.J., Jr., Haley, J.C., Nichols, D.J., Hammons, P.M., and Ponton, J.D., 1988, Interactions of Rocky Mountain foreland and Cordilleran thrust belt in the Lima region, southwest Montana, in Schmidt, C.J., and Perry, W.J., Jr., eds., Interaction of the Rocky Mountain foreland and Cordilleran thrust belt: Geological Society of America Memoir 171, p. 267-290.

Perry, W.J., Jr., Dyman, T.S., and Sando, W.J., 1989, Southwestern Montana recess of Cordilleran thrust belt, in French, D.E., and Grabb, R.F., Geologic resources of Montana: Montana Geological Society 1989 Field Conference Guidebook: Montana Centennial Edition, v. 1, p. 261-270.

Peterson, J. A., 1985, Regional stratigraphy and general petroleum geology of Montana and adjacent areas, in Tonneson, J.J., ed., Montana Oil and Gas Fields Symposium 1985: Montana Geological Society, v. 1, p. 5-45.

Sheedlo, M.K., 1984, Structural geology of the northem Snowcrest Range, Beaverhead and Madison Counties, Montana: Westem Michigan University, unpublished M.S. thesis, Kalamazoo, $132 \mathrm{p}$. 
Schmidt, C. J., O'Neill, J. M., and Brandon, W.C., 1988, Influence of Rocky Mountain foreland uplifts on the development of the frontal fold and thrust belt, southwestern Montana, in Schmidt, C.J., and Perry, W.J., Jr., eds., Interaction of the Rocky Mountain foreland and Cordilleran thrust belt: Geological Society of America Memoir 171, p. 171-201.

Tissot, B.P., and Welte, D.H., 1978, Petroleum formation and occurrence, A new approach to oil and gas exploration: Berlin, Springer-Verlag, 538 p.

Tysdal, R.G., 1988, Geologic map of the northeast flank of the Blacktail Mountains, Beaverhead County, Montana: U.S. Geological Survey Miscellaneous Field Studies Map MF-2401, scale 1:24,000.

Wardlaw, B.R., and Pecora, W.C., 1985, New Mississippian-Pennsylvanian stratigraphic units in southwest Montana and adjacent Idaho: U.S. Geological Survey Bulletin 1656-B, p. B1-B9.

Zeigler, J. M., 1954, Geology of the Blacktail area, Beaverhead County, Montana: Harvard University, unpublished Ph. D. dissertation, Cambridge, Massachusetts, $147 \mathrm{p}$. 